\title{
Game Labirin Let's Clear Up The World Menggunakan Metode Game Development Life Cycle
}

\author{
Ahmad Chusyairi ${ }^{1 *}$ \\ ${ }^{1}$ Teknik Informatika; Universitas Bina Insani; Jl. Siliwangi No.6 Rawa Panjang Kota Bekasi, \\ Telp. 021 82436886; e-mail: ahmadchusyairi@binainsani.ac.id \\ * Korespondensi: Ahmad Chusyairi e-mail: ahmadchusyairi@binainsani.ac.id
}

Diterima: 10 Mei 2020; Review: 14 Mei 2020; Disetujui: 30 Mei 2020;

Cara sitasi: Chusyairi A. 2020. Game Labirin Let's Clear Up The World Menggunakan Metode Game Development Life Cycle. Informatics for Educators and Professionals. Vol. 4 (2): 183-192

Abstrak: Game Labirin Let's Clear Up The World menceritakan kisah seorang anak yang mencintai kebersihan dan keindahan untuk mengubah lingkungan kotor menjadi tempat yang lebih bersih. Game Development Life Cycle digunakan sebagai metode dalam penelitian ini dengan tahapan Initation, Pre-production, Production, Testing, Beta External Testing dan Release. Kreasi aset berupa tokoh Coris, tokoh Fairy, boneka beruang (bear), paper trash, trash can, karakter lain yang terdapat pada game labirin adalah: Plastic, Trash Clown, Slime, Mesin Slimers Mary (ibu) dan Lily (anak), Pintu Gua dan coding diintegrasikan dengan menggunakan tool RPG Maker. Hasil yang didapatkan adalah Game Labirin Let's Clear Up The World menumbuhkan kesadaran manusia terhadap kebersihan lingkungan yang dapat menyebabkan kerusakan lingkungan dan timbulnya wabah penyakit terutama keberadaan sampah yang menumpuk, sehingga menyebabkan perubahan lingkungan menjadi daerah kumuh dengan pertumbuhan wabah.

Kata kunci: Game Labirin, Let's Clear Up The World, Game Development Life Cycle

Abstract: The Let's Clear Up The World Labyrinth game tells the story of a child who loves cleanliness and beauty to turn a dirty environment into a cleaner place. Game Development Life Cycle is used as a method in this study with the stages of Initation, Pre-production, Production, Testing, Beta External Testing and Release. Asset creations in the form of Coris figures, Fairy figures, teddy bears, paper trash, trash cans, other characters found in the maze game are: Plastic, Trash Clown, Slime, Slimers Machines Mary (mother) and Lily (children), Door Cave and coding are integrated using the RPG Maker tool. The results obtained are the Let the Clear Up The World Labyrinth Game to raise human awareness of environmental cleanliness that can cause environmental damage and disease outbreaks, especially the presence of garbage that has accumulated, causing environmental changes to become slums with outbreak growth.

Keywords: The Labyrinth Game, Let's Clear Up The World, Game Development Life Cycle

\section{Pendahuluan}

Hiburan dalam bentuk multimedia dibuat dengan menarik agar pengguna mendapatkan kepuasaan disebut game. Pengenalan budaya daerah dengan menggunakan game edukasi kepada masyarakat umum. Jadi selain menarik minat belajar, melalui game edukasi dapat mengenalkan dan menciptakan rasa bangga tentang salah satu budaya daerah, sehingga dibutuhkan sebuah aplikasi game tentang budaya yang mudah digunakan dan terlihat menarik sehingga dapat membantu dalam bidang edukasi kebudayaan daerah. Salah satu yang penting untuk dilestarikan adalah budaya dalam busana Tari Bali. Aplikasi Game Edukasi Busana Tari Bali dari aspek entertainment menghasilkan $60 \%$ nilai baik dan $40 \%$ nilai sangat baik [1].

Pengembangan game bersifat pendidikan sangat menarik. Salah satu kelebihannya adalah memvisualisasikan permasalahan pada dunia nyata melalui game. Salah satunya adalah edukasi melalui game bertipe Maze. Rancangan penelitian eksperimen dengan desain penelitian Single Subject Research (SSR) digunakan sebagai metode. Logika baseline adalah 
prosedur desain A-B yang disusun dalam penelitian ini. Jenis penelitian ini menggunakan rancangan penelitian eksperimen dengan desain penelitian SSR atau dalam bahasa Indonesia dikenal dengan penelitian subjek tunggal. Sampel penelitian pada jenis SSR difokuskan pada individu [5].

Pada tanggal 24 Oktober 2015 dikeluarkan rilis RPG Maker MV versi terbaru di mana terdapat perubahan fitur yang lebih lengkap dibandingkan versi sebelumnya. Update fitur pada RPG Maker MV, yaitu: 1) Hasil dari pembuatan game dengan RPG Maker MV bisa dijalankan pada platform windows, MacOS, Android, iOS, atau HTML5 yang digunakan dalam menjalankan web browser, 2) Pengendalian game pada RPG Maker MV dengan keyboard, mouse atau touch-screen, 3) Kapasitas database dapat menampung lebih kurang 2000 item, 4) Terdapat 3 lapis Layer map, 5) Resolusi layar adalah $816 \times 624$ pixel, sedangkan versi sebelumnya adalah 544×416 pixel, 6) Tersedianya Event search [4].

Penelitian dengan judul "Rancang Bangun Aplikasi Game Edukasi Ragam Budaya Indonesia" telah berhasil dibangun dengan kesimpulan: a) telah dihasilkan aplikasi desktop game edukasi ragam budaya Indonesia sebagai sarana permainan dan pembelajaran yang mudah dan menarik untuk anak, b) dari hasil pengujian dapat disimpulkan bahwa game ragam budaya Indonesia ini dapat memberikan dampak positif berupa wawasan dan pengetahuan mengenai ragam kebudayaan indonesia pada anak-anak [6].

Game pendidikan memiliki kelebihan jika dicompare dengan cara yang konvensional. Visualisasi dari permasalahan menjadi nyata adalah salah satu kelebihan utama dari game pendidikan. Scrath adalah proyek game dari MIT yang sangat berguna dalam meningkatkan logika dan pemahaman terhadap masalah. Game pendidikan dapat menunjang proses edukasi menurut hasil penelitian sebelumnya [7].

Pengguna dapat memainkan peran dalam merajut sebuah cerita adalah Game RPG. Karakter pada tokoh game dimiliki pengguna. Jenis game lainnya memiliki perbedaan dibandingkan Game RPG yang disebut strategy game atau seperti action game pada Mario Bros. Karakter tertentu dimiliki pada game RPG, misal tokoh menjadi tidak lemah, pengguna bisa memasukkan nama dari tokoh yang sedang bermain, aturan dalam konflik tokoh dan pratinjau dalam dunia semu yang digunakan (geografi, nama raja, sejarah, dan lain-lain). Program dalam membuat game RPG adalah RPG Maker, di mana menggunakan alat bantu yang disediakan dalam program yang dibuat grup Jepang yang diberi nama ASCII, lalu dilanjutan Enterbrain. Amerika Utara, Australia, Asia dan Eropa merupakan tempat rilis RPG Maker [8].

Metode yang disukai anak adalah permainan yang dapat dijalankan pada handphone kapan saja dan dimana saja. Genre yang disukai pengguna yang berfungsi sebagai tokoh utama dalam game, sehingga pengguna dapat menyelesaikan game adalah Genre Role Playing Game (RPG). Software penyedia game yang memiliki grafik 2 dimensi (2D) salah satunya adalah RPG Maker MV. Mac OS, Windows, Android, dan Web Browser tempat dilakukan export sebagai luaran dari RPG Maker MV. Sistem operasi Android sering digunakan oleh user saat ini. Versi yang dikeluarkan oleh android menjadi bukti sebagai OS yang sering digunakan user [9].

Pengembangan media pembelajaran untuk meningkatkan ketrampilan berpikir secara kritis siswa dengan menggunakan Role Playing Game (RPG) Maker XP. Model DDD-E yang dikembangkan Dick dan Carey yang sudah dimodifikasi dapat dilakukan adaptasi untuk media pembelajaran. Rancangan One Group Pretest-Postest Design diuji cobakan pada SMA Negeri 2 Probolinggo dilakukan uji coba untuk media pembelajaran pada tiga kelas, diantaranya XI MIPA 3, XI MIPA 2 dan XI MIPA 1. Untuk meningkatkan tek ketrampilan berpikir secara kritis digunakan teknis analasis data, diantaranya statistik inferensial dan deskriptif kualitatif. Media pembelajaran layak dikembangkan dengan kategori yang sangat baik merupakan hasil dari penelitian [10].

Game akuntasi dengan RPG Maker menjadi objek dalam penelitian ini. Angket digunakan dalam teknik mengumpulkan data. Deskriptif kuantitatif dan kualitatif digunakan dalam analisis dalam memperoleh data melalui angket. Game akuntansi berbasis RPG Maker dikembangkan dengan tahap: 1) Pendenifisian, 2) Perancangan, 3) Pengembangan, dan 4) Penyebaran [11].

Media game yang sebagai media yang menghibur, media pembangkit motivasi yang efektif dan juga sebagai media informasi. Sejarah Terbentuknya Kota Samarinda menjadi dasar dibangunnya game di kota Samarinda. Jenis game Role Playing Game (RPG) merupakan game untuk seluruh permainan sesuai dengan story pada game sejarah kota Samarinda. $R P G$ 
Editor Engine sebagai mesin yang mengubah RPG dengan RPG Maker MV Ace untuk membangun game tersebut. Sejarah kota Samarinda dibangun sesuai dengan flow cerita pada storyline game. Fitur dengan macam misi dan sentuhan graphic $2 \mathrm{~d}$ dibangun untuk mendukung game ini [12].

Ketergantungan pada generasi muda pada penggunaan teknologi yang ditunjukkan pada penelitian pada tahun 2012 di mana ada umur yang berada di bawah 24 bulan sebesar $40 \%$ yang sudah memakai handphone dan smartphone, usia anak yang beradai di atas 96 bulan atau sebesar $75 \%$ juga memakai teknologi yang terbaru. Perangkat pada teknologi yang berbasis mobile di atas 120 menit dan umumnya digunakan dalam permainan, melihat video, menggunakan media sosial dan kegiatan lainnya sedangkan dampak negatifnya adalah ada permainan yang bersifat kurang mendidik, sehingga akan berdampak pada pengurangan lama belajar anak tersebut dan menjadikannya kurang rajin dalam belajar. Pengujian terhadap permainan dilakukan kepada 30 orang di mana hasilnya adalah permainan dapat membantu dalam pengenalan daerah di Kota Solo Raya atau sebesar $75 \%$ dan permainan dinyatakan bersifat menarik sebesar $79 \%$ [13].

Pada penelitian ini dapat disimpulkan bahwa peningkatan dalam output luaran belajar siswa di SDN 1 Nangsri, Kebakramat, Jawa Tengah dengan menjadikan game edukatif sebagai media pembelajaran. Kuesioner diberikan sebagai pengujian terhadap game edukatif terhadap guru dan siswa di mana hasilnya $86 \%$ kedua pihak tersebut memberikan persetujuan mengenai game edukasi tersebut dalam upaya peningkatan minat anak usia dalam sekolah dasar untuk pengenalan pahlawan yang bersifat nasional dan meningkatkan siswa dalam belajar tokoh tersebut dengan didukung pada hasil post-test dan pre test [14].

Game Zinc Citrate adalah permainan yang memberikan pendidikan mengenai kebersihan dalam menjaga mulut di mana android sebagai basisnya dan action sebagai genre dari game ini. Perspektif dalam game ini adalah Third Person Shooter yang mendeskripsikan mengenai kondisi anak terutama mulut yang tidak bersih dapat menjadikan adanya bakteri pada mulut. Player yang berperan dalam pengendalian dengan tokoh pahlawan, yaitu Zat Zinc Citrate dapat membasmi bakteri pada mulut anak. Tujuan pada game ini adalah pengenalan untuk menjaga kebersihan mulut pada anak. Extreme Programming adalah metode yang digunakan dalam membangun game ini yang terdiri dari: planning, design, coding dan testing. Game ini dapat membantu anak dalam melakukan permainan dan memberikan kesadaran kepada anak dalam menjaga kebersihan mulut. Pengembangan pada game ini dilanjutkan untuk level-levelnya dan dihubungkan dengan database dalam save nilai [15].

Penentuan kualitas dari software untuk mendeskripsikan dan mendapatkan keperluan kualitas sesuai dengan karakter pada tokoh dari software tersebut yang dapat menyebabkan pembentukan karakter tokoh pada software pada game yang berbasis mobile menjadi lebih berkualitas adalah hasil dari penelitian ini [16].

Permainan yang memberikan pendidikan dan memberikan hasil pada penerapan dan testing adalah Game Save Family from Malaria. Kesimpulannya adalah: 1) Permaian yang memberikan pendidikan pada game ini menyajikan knowledge kepada player terutama anak mengenai penyakit Malaria dan cara pencegahan dari penyakit tersebut, 2) Game ini memberikan pelatihan dan informasi yang edukatif dan interaktif kepada player yang berdampak pada upaya pencegahan terhadap penyakit malaria, 3) Game ini menyajikan hiburan kepada player yang mana tahapan cerita pada game ini dapat memberika informasi terhadap penyakit malaria [18].

Game onet adalah permainan yang user friendly untuk player. Perancangan pada Game Onet Wawasan Nusantara (OWA) sebagai tujuan dari penelitian ini. Digital Games Based Learning-Instructional Design (DGBL-ID) sebagai metode dalam membangun game dengan alur: analysis, design, development, implementation. Pemilihan metode digunakan untuk menghubungkan kebudayaan dengan kurikulum dalam pembelajaran melalui game yang berperan sebagai hiburan dan edukasi. Prototipe game sebagai dasar game untuk pengembangan selanjutnya sebagai hasil dari penelitian ini. Game ini jika diterapkan untuk player yang ada di Indonesia akan memberikan penyelesaian sebagai usaha dalam mendukung pemerintah dalam pelestarian budaya Indonesia [19].

Kesadaran manusia terhadap kebersihan lingkungan yang kurang, menyebabkan kerusakan lingkungan dan timbulnya wabah penyakit, terutama keberadaan sampah yang menumpuk, menyebabkan perubahan lingkungan menjadi daerah kumuh dengan pertumbuhan pesat wabah. Dalam memudahkan kesadaran terhadap kebersihan lingkungan tersebut, maka 
dibuat game yang menceritakan bagaimana seorang anak yang mencintai kebersihan dan keindahan mengubah lingkungan yang kotor menjadi tempat yang lebih bersih. Untuk membersihkan area, Anak tersebut harus menemukan seluruh sampah yang terdapat pada area itu dan memilahnya kedalam tempat sampah sesuai dengan jenis sampah yang ditemukan.

\section{Metode Penelitian}

Game Development Life Cycle digunakan sebagai metode dalam penelitian Game Labirin Let's Clear Up The World ini pada gambar $1[2,3]$.

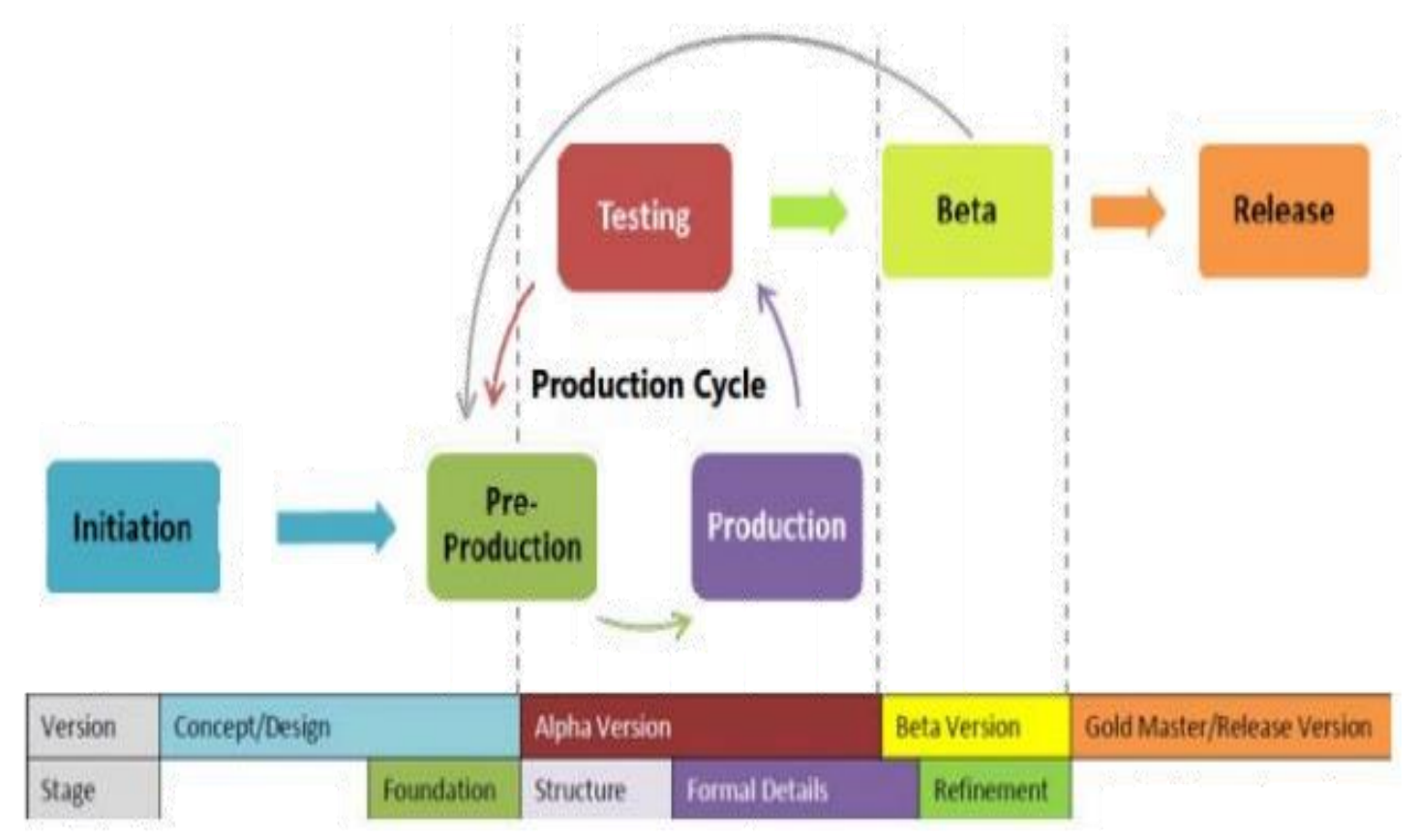

Sumber Hasil Penelitian: R. Ramadan and Y. Widyani (2013)

\section{Gambar 1. Game Development Life Cycle}

Penjelasan dalam penelitian Game Labirin Let's Clear Up The World menggunakan metode Game Development Life Cycle adalah: 1). Initiation, pengembang berkumpul, melakukan brainstorming dengan mengumpulkan gagasan dengan tim pengembang dan mencari penyelesaian dari masalah yang ada dengan berdiskusi mengenai game labirin yang akan dibangun. 2). Pre-production, desain produksi game labirin yang terdiri dari desain game dan prototipe dengan dibantu tool desain grafis. 3). Production, penyempurnaan desain dan prototipe game labirin dengan kreasi aset seperti: Coris, Fairy, Boneka berbentuk Beruang atau Bear, Paper Trash dan Trash Can dan karakter lain yang terdapat pada game labirin adalah: Plastic, Trash Clown, Slime, Mesin Slimers Mary (ibu) dan Lily (anak), dan Pintu Gua dengan menggunakan pemrograman dalam bentuk coding, misal: plugins dan lainnya serta diintegrasikan antara aset dan coding dengan tool RPG Maker. 4). Testing, pengujian terhadap prototipe yang dibangun yang dilakukan pengembang untuk pengujian kegunaan dan fungsi. 5). Beta External Testing, untuk mendeteksi error dan keluhan dari penguji untuk game labirin. Beta berada diluar siklus produksi, tetapi hasil dari pengujian ini dapat menyebabkan tim akan mengulangi siklus lagi. 6). Release Game, yang sudah selesai dibangun dan lulus beta external testing menunjukkan game labirin sudah ready untuk dipublish ke umum dengan final build dari game labirin resmi dirilis.

\section{Hasil dan Pembahasan}

Hasil dan pembahasan dalama penelitian Game Labirin Let's Clear Up The World sebagai berikut: a). Initation Game Labirin Let's Clear Up The World menceritakan kisah seorang anak yang mencintai kebersihan dan keindahan untuk mengubah lingkungan kotor menjadi tempat yang lebih bersih. Untuk membersihkan area, anak tersebut harus menemukan 
seluruh sampah yang terdapat pada area itu dan memilahnya ke dalam tempat sampah sesuai dengan jenis sampah yang ditemukan. Tujuan game ini adalah mengumpulkan sampah dan mengubahnya menjadi alat untuk membasmi wabah yang ditimbulkan dari kerusakan lingkungan dari keadaan sebelumnya sehingga menjadikan lingkungan aman dan bebas dari wabah. b). Pre-production pembuatan desain dan prototipe pada game labirin berisi: taman, macam-macam kreasi aset (boneka beruang atau bear, paper trash, dan karakter lain yang terdapat pada game labirin adalah: Plastic, Trash Clown, Slime, Mesin Slimers Mary (ibu) dan Lily (anak), Pintu Gua yang digunakan untuk memudahkan dalam pembuatan game yang dijelaskan pada gambar 2.

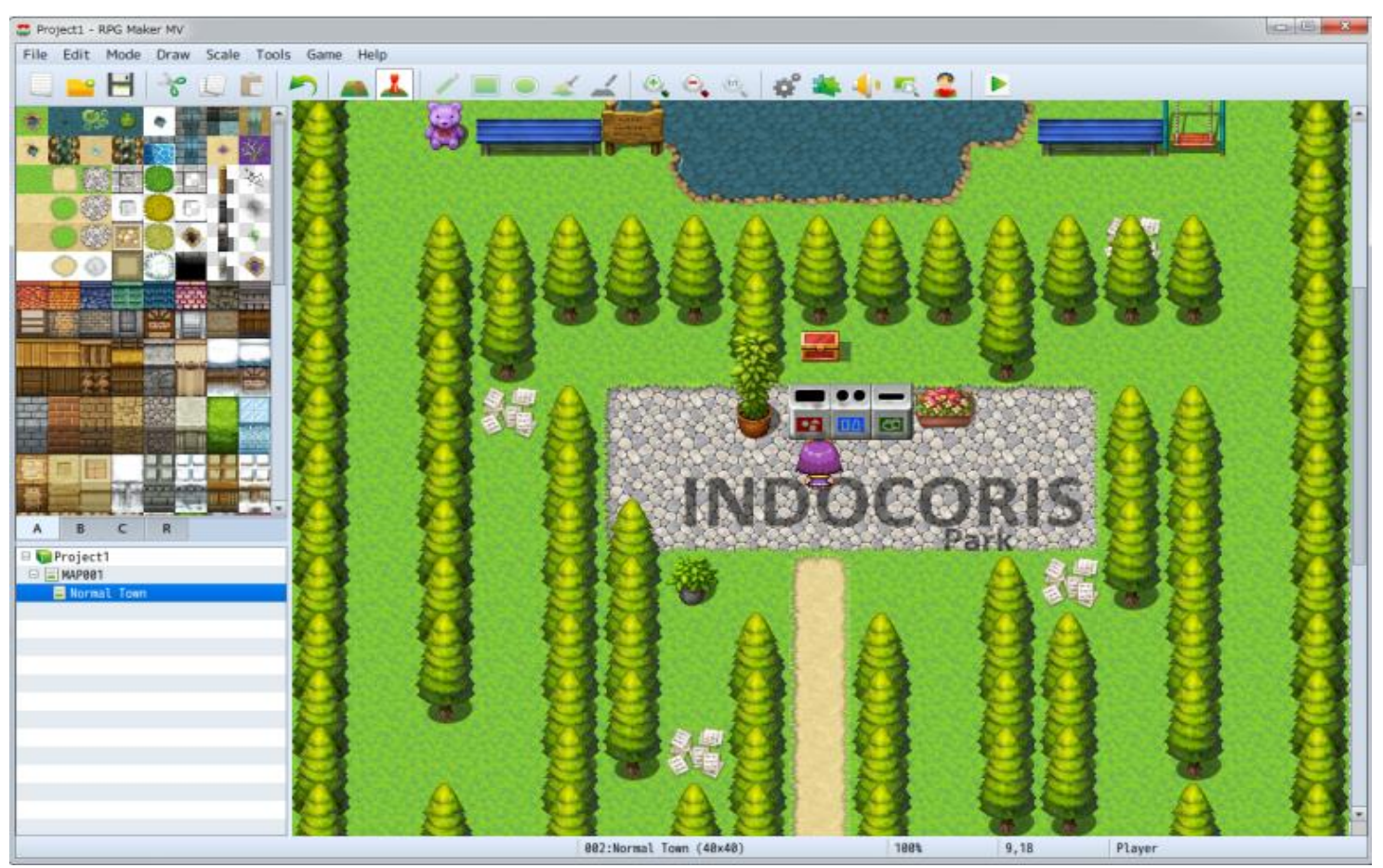

Sumber: Hasil Penelitian (2020)

\section{Gambar 2. Plugins Game Labirin}

c). Production Pada tahap production terdapat aset yang dikreasikan pada game labirin Let's Clear Up The World yang menjelaskan karakter dan tokoh, yaitu: tokoh Coris, tokoh Fairy, boneka beruang (bear), paper trash dan trash can pada tabel 1.

Tabel 1. Aset Game Labirin

No $130 \begin{gathered}\text { Nama } \\ \text { Coris }\end{gathered} \begin{aligned} & \text { Seorang anak yang mencintai } \\ & \text { kebersihan lingkungan dan ingin } \\ & \text { menciptakan lingkungan yang } \\ & \text { bebas sampah }\end{aligned}$




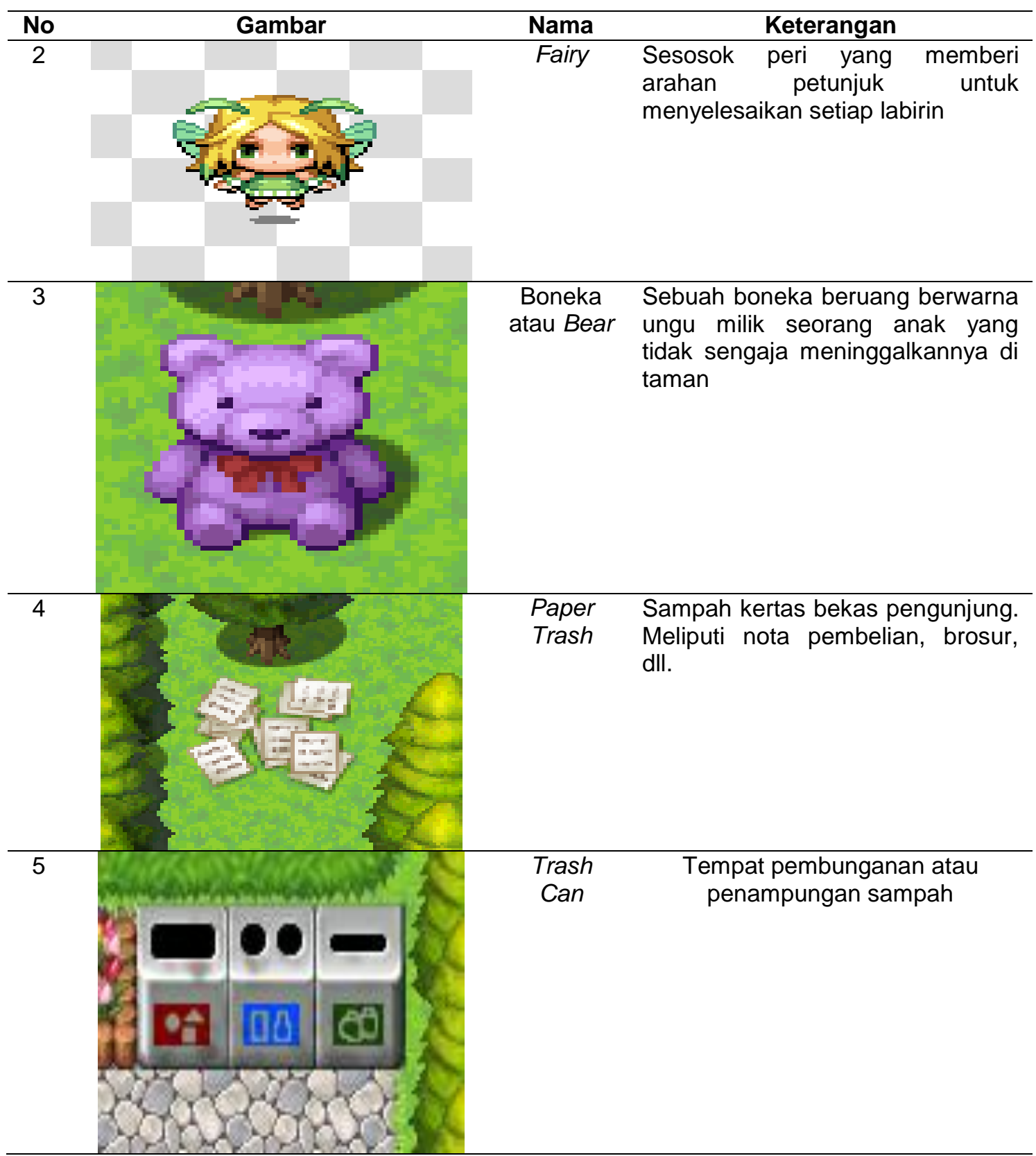

Sumber: Hasil Penelitian (2020)

Karakter lain yang terdapat pada game labirin adalah: a) Plastic Trash digunakan untuk sampah plastic bekas pengunjung, meliputi kantong kresek, botol plastik, dan lainnya, b) Clown digunakan untuk NPC 1, c) Slime digunakan untuk kuman yang berbentuk slime. Terbentuk akibat gumpalan sampah yang terkena hujan akhirnya terciptalah kuman slime, d) Mesin Slimers digunakan untuk mesin yang memproduksi Slimers yang beroperasi dengan tenaga sampah dengan bahan campuran air untuk finishing produksi, e) Mary (ibu) dan Lily (anak) di mana Lily adalah pemilik boneka yang tertinggal di Labirin Taman 1. Dan Mary adalah Ibunya Lily yang selalu mendampingi Lily setiap saat, dan f) Pintu Gua adalah pintu untuk menuju ke ending of the game.

Salah satu pemrograman dengan coding terdapat pada plugins AltMenuScreen.js pada gambar 2. Plugins lain yang digunakan dalam game labirin ini adalah AltSaveScreen.js, Community_Basic.js, EnemyBook.js, ItemBook.js, MadeWithWV.js, SimpleMsgSideView.js, TtileCommandPosition.js, WeaponSkill.js, dan YEP1Core.js. 


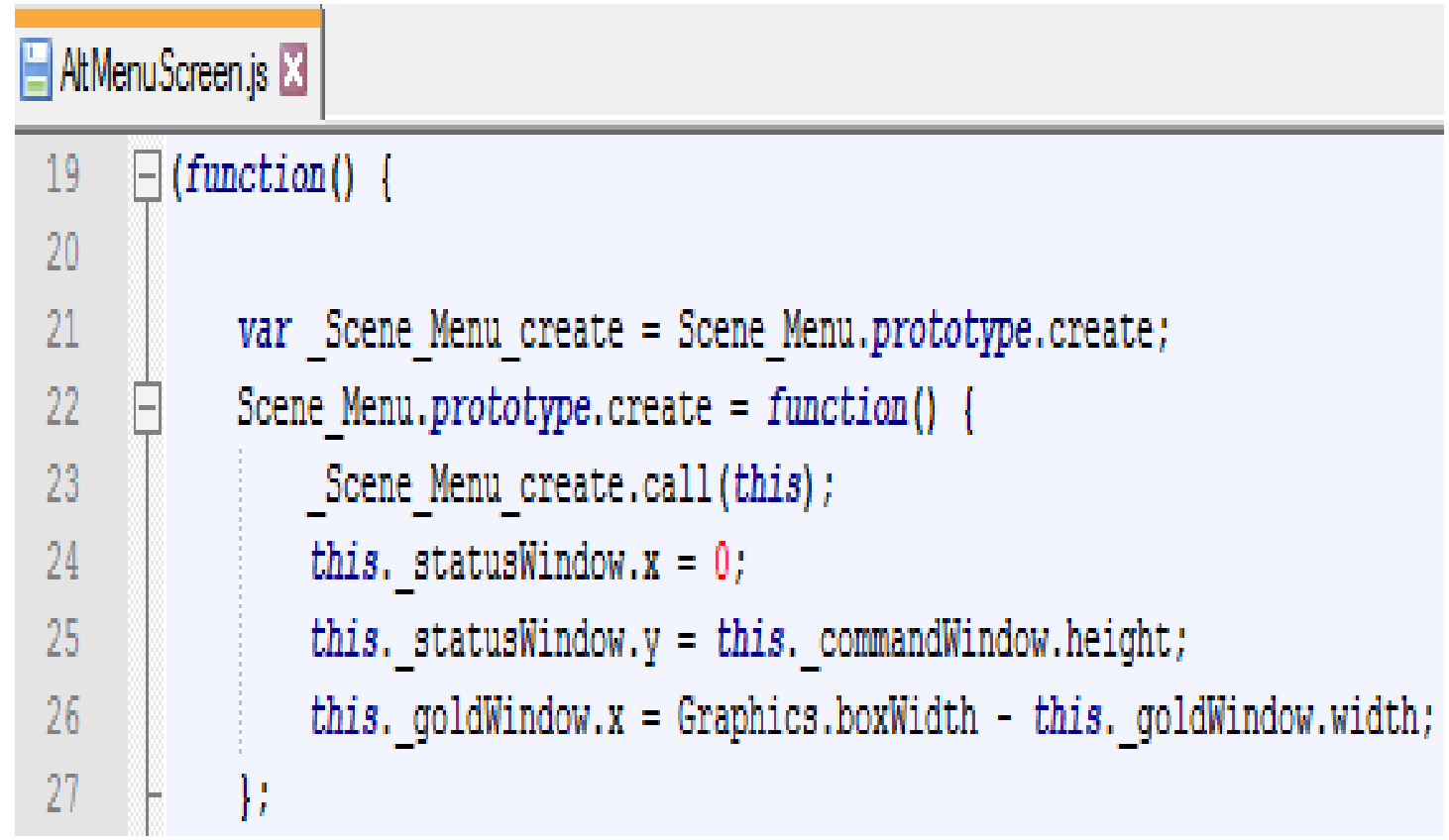

Sumber: Hasil Penelitian (2020)

\section{Labirin Taman 1}

Gambar 3. Plugins Game Labirin

Pada labirin taman 1, pemain dihadapkan dengan sesosok peri "Fairy". Peri "Fairy" tersebut akan memberikan sebuah misi untuk mengumpulkan sampah kertas dan memasukkanya ke dalam tempat sampah yang telah disediakan. Pada labirin taman 1 ini pemain hanya diharuskan mengumpulkan satu jenis sampah, yaitu sampah kertas atau "Paper Trash". Setiap paper trash tersebar di setiap penjuru area taman, pemain harus menemukan 4 paper trash dan kemudian memasukkannya kedalam Tempat Sampah atau "trash can" untuk dapat melewati labirin taman 1 ini. Kemudian akan muncul save screen untuk menyimpan proses permainan.

Ada 2 buah Event Rahasia yaitu: 1). Sebuah Boneka yang ada di pojok kiri atas taman. Boneka tersebut ada milik seorang anak yang menangis didampingi oleh lbunya pada taman labirin 2, anak tersebut tidak sengaja meninggalkan Bonekanya. Disaat karakter utama memberikan Boneka tersebut kepada lbu dari anak tersebut maka anak tersebut akan berhenti menangis dan karakter utama akan mendapat bonus 50Gp. 2). Di belakang trash can terdapat sebuah Peti yang berisi 50G. peti tersebut dapat diperoleh dengan cara menarik sebuah pot bunga yang ada di samping trash can.

Pada Labirin Taman 1 ini ada 250G yang dapat diperoleh oleh Coris untuk mengumpulkan Gold $(\mathrm{G})$. dari pengumpulan sampah diperoleh 200G dan 50G dari peti yang berada dibelakang trash can.

\section{Labirin Taman 2}

Pada labirin taman 2, sama seperti labirin taman 1 sebelumnya. Karakter utama "Coris" harus membersihkan beberapa sampah yang berserakan di taman.Pada taman labirin 2 ini ada 2 tipe sampah yang harus dibersihkan, yaitu: sampah kertas "paper trash" dan sampah plastik "plastic trash". Ada 5 sampah kertas dan 4 sampah plastik pada gambar 9. Ada 5 sampah kertas "paper trash" dan 4 sampah plastik "plastic trash" yang tersebar pada taman labirin 2 ini. Jika seluruh sampah sudah dibersihkan kemudian sampah harus dimasukkan ke tempat sampah "trash can". Setelah selesai, Akan muncul peri "Fairy" yang akan mentransfer karakter utama "Coris" menuju taman labirin 3. Ada sebuah Event yang dapat diselesaikan untuk menambah perolehan G "Gold". Pada taman labirin 1 sebelumnya ada sebuah boneka yang tergeletak di sebelah bangku taman. Boneka tersebut milik seorang anak yang menangis dan didampingi oleh ibunya pada taman labirin 2. Karakter utama "Coris" berbicara pada Ibunya tersebut. Jika "Coris" membawa bonekanya maka ibu dari anak tersebut akan memberikan bonus 50G. Pada Labirin Taman 2 ini Coris dapat mengumpulkan 500G untuk menambah 
perolehan Gold (G). Dari pengumpulan sampah diperoleh 450G dan 50G dari pengembalian boneka.

\section{Labirin Taman 3}

Pada labirin taman 3 adalah labirin taman yang klimaks. Karakter utama "Coris" diberikan misi untuk membersihkan taman. Kita diharuskan untuk mengumpulkan sampah-sampah dan memasukkannya kedalam mesin, sehingga sampah-sampah tersebut akan menjadi sebuah energi yang akan menjalankan mesin dan bahan untuk membuat slimers. Ada 5 sampah kertas dan 10 sampah plastik. Slimers adalah alat untuk mengusir para slime yang menghadang disekitar gua. Sebelumnya, setelah energi didapatkan karakter utama harus mengambil sebucket air untuk menyelesaikan proses pembuatan slimers. Untuk mendapatkan air tersebut, bisa didapatkan di sekitar gua. Setelah itu, karakter utama mendapatkan 5 buah slimers dan pergi menuju gua kemudian melemparkan botol slimers dan menimbulkan asap yang dapat membuat para slime menjauh dari area tersebut. Pada akhirnya, disaat slime menjauh dan menghilang, karakter utama "Coris" akan memasuki Gua Labirin Taman 3 dan perjalanan pada Labirin ini selesai.

Pada Labirin Taman 3 ini Coris dapat mengumpulkan 2000G untuk menambah perolehan Gold (G). 1500G dari perolehan pengumpulan Sampah dan 500G dari suksesnya pembuatan Slimers dan mengusir para Slime. a).Testing: Pengujian terhadap prototipe yang dibangun yang dilakukan pengembang untuk pengujian kegunaan dan fungsi, misal: ketika pengguna menemukan sampah berupa kertas (paper trash) akan tampil pertanyaan: Do you want to take it? dan selanjutnya akan menampilkan dua pilihan, yaitu: Yes dan No. Jika player melakukan pilihan Yes, maka kertas tersebut akan diambil untuk ditempatkan pada tempat sampah yang dapat menyebabkan misi berhasil atau Trash Can dan Jika player melakukan pilihan No, maka paper trash tersebut tidak dapat diambil yang akan dapat menyebabkan misi menjadi gagal. b). Beta External Testing: Untuk mendeteksi error dan keluhan dari penguji untuk game labirin. Beta berada diluar siklus produksi, tetapi hasil dari pengujian ini dapat menyebabkan tim akan mengulangi siklus lagi. Salah satu contoh setelah yang terjadi adalah ketika masuk pada taman labirin 2 di mana sampah berupa kertas (paper) dan plastik (plastic) yang dicari tidak sama dengan yang ditampilkan, misal: What do you to throw? Paper $=4 / 5$ Plastic $=4 / 4$ dengan penjelasan di mana player sudah mendapatkan 4 sampah berupa plastik dari 4 yang sudah ditampilkan sedangkan player hanya mendapatkan 4 sampah berupa paper dari 5 yang ditampilkan dengan catatan: sampah kertas yang diminta ada 5 sedangkan sampah kertas yang ditampilkan pada game labirin hanya ada 4, hal ini dapat menyebabkan akan adanya keluhan dari penguji di mana player tidak dapat menyelesaikan game labirin atau melanjutkan ke level selanjutnya (labirin taman 3) karena terdapat error pada algoritma game ini pada gambar 4.

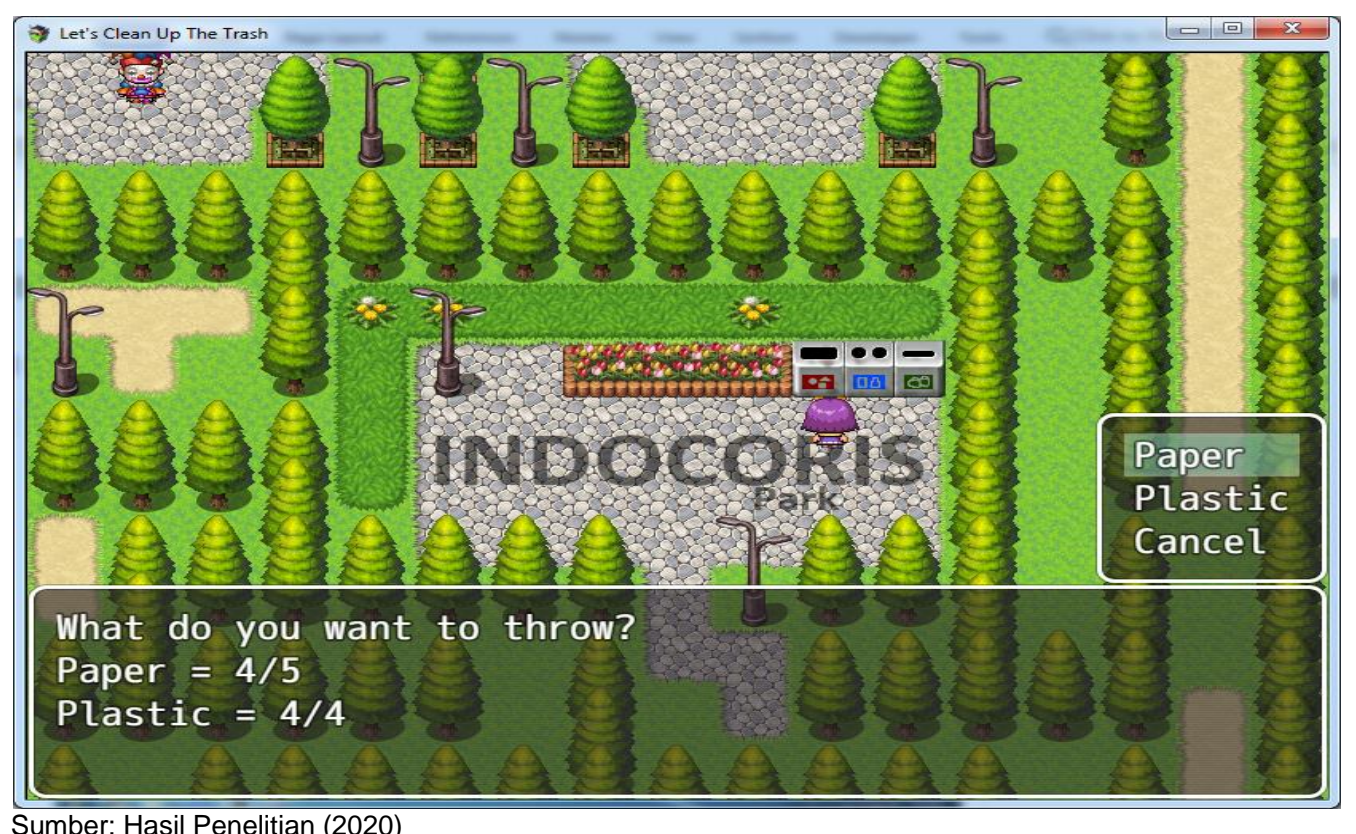

Gambar 4. Beta External Testing Game Labirin 
c). Release Game, yang sudah selesai dibangun dan lulus beta external testing menunjukkan game labirin sudah ready untuk dipublish ke umum dengan final build (game.exe) dari game labirin resmi dirilis. Folder game labirin berisi: audio, data, fonts, icon, img, js, movies, save, dan file project.

\section{Kesimpulan}

Game Labirin Let's Clear Up The World adalah game yang perlu dikembangkan karena dapat menambah wawasan seseorang dan dapat menyalurkan pendidikan dengan cara yang menyenangkan. Kebersihan lingkungan adalah hal yang sangat penting karena kebersihan adalah sebagian dari iman, Selain itu, jika lingkungan kita bersih maka akan sangat sedap dipandang dan jauh dari penyakit. Ada banyak cara untuk mendaur ulang sampah, salah satunya dengan cara membuat mesin yang dapat membuat sampah menjadi energi. Game Development Life Cycle digunakan sebagai metode dalam penelitian ini dengan tahapan Initation, Pre-production, Production, Testing, Beta External Testing dan Release Game yang sudah selesai dibangun dan lulus beta external testing menunjukkan game labirin sudah ready untuk dipublish ke umum dengan final build (game.exe) dari game labirin resmi dirilis. Metode Game Development Life Cycle dapat membantu dalam pembangunan game labirin sesuai dengan kebutuhan pengguna. Kreasi aset berupa tokoh Coris, tokoh Fairy, boneka beruang (bear), paper trash, trash can, karakter lain yang terdapat pada game labirin adalah: Plastic, Trash Clown, Slime, Mesin Slimers Mary (ibu) dan Lily (anak), Pintu Gua dan coding diintegrasikan dengan menggunakan tool RPG Maker.

Saran untuk penelitian selanjutnya adalah pembuatan tokoh dengan karakter yang lebih lengkap pada game labirin, dan pengembangan tingkat kesulitan pada setiap levelnya dalam game labirin ini.

\section{Referensi}

[1] N. K. Yuliastin, I. M. Sukarsa and N. K. A. Wirdiani, "Aplikasi Game Edukasi Busana Tari Bali Pada Smartphone Berbasis Android," Merpati, vol. 2, no. 3, pp. 280-290, 2014.

[2] A. Chusyairi, J. S. L. Wibowo and A. K. Winata, "Game Gandrung Stories untuk Edukasi Kebudayaan Menggunakan GDLC," Jasika, vol. 1, no. 1, pp. 67-75, 2020.

[3] B. F. Ananda and A. Chusyairi, "Perancangan Game Virus Survivor untuk Pendidikan Kesehatan dengan Metode Game Development Life Cycle," JTIM: Jurnal Teknologi Informasi dan Multimedia, vol. 1, no. 2, pp. 7-84, 2019.

[4] Nadifah, L. U, "Pengembangan Game "Paduka.exe" Berbasis RPG Maker MV Sebagai Media Belajar Mandiri Pada Materi Fungsi Komposisi," in Program Studi Pendidikan Matematika Fakultas Tarbiyah dan Keguruan Universitas Islam Negeri Sunan Ampel Surabaya, 2018.

[5] Suela, I. K., \& Wijiastuti, A, "Permainan Maze Untuk Mereduksi Perilaku Self Stimulation Pada Anak Autis," Jurnal Pendidikan Khusus, vol. 7, no. 3, pp.1-6, 2014.

[6] B. Pane, X. Najoan and S. Paturusi, "Rancang Bangun Aplikasi Game Edukasi Ragam Budaya Indonesia," E-Journal Teknik Informatika, vol. 12, no. 1, pp. 1-9, 2017.

[7] A. V. Vitianingsih and T. Informatika, "Game Edukasi Sebagai Media Pembelajaran Pendidikan Anak Usia Dini," J. Inf., vol. 1, no. 1, pp. 1-8, 2016.

[8] F. H. Saputri and D. Pratiwi, "Pembuatan Game RPG Roro Jonggrang dengan RPG Maker MV," Seminar Nasional Cendekiawan, Lembaga Penelitian, Universitas Trisakti University, 2016, pp.9.1-9.9.

[9] P. Sokibi and I. K. W. Adnyana, "Game Edukasi RPG Seal Breaker menggunakan RPG Maker MV Berbasis Android," Jurnal Bahasa Rupa, vol. 2, no. 1, pp. 68-79, 2018.

[10] N. Ningsih, P. Prabowo and W. Widodo, "Pengembangan Media Pembelajaran Berbasis Role Playing Game (RPG) Maker XP pada Materi Kesetimbangan Benda Tegar untuk Melatihkan Keterampilan Berpikir Kritis Siswa," Jurnal Penelitian Pendidikan Sains (JPPS), vol. 6, no. 1, pp. 1107-1112, 2016.

[11] A. D. Pratiwi \& E. M. Sagoro, "Pengembangan Game Akuntansi Berbayar RPG Maker sebagai Media Pembelajaran Akuntansi Siswa Kelas X SMK Negeri 1 Karanganyar Kabupaten Purbalingga," Kajian Pendidikan Akuntansi Indonesia, vol. 6, no. 3, pp. 1-11, 2017.

[12] S. Maharani, H. R. Hatta \& F. A. Selvyani, "Game Sejarah Terbentuknya Kota Samarinda 
Menggunakan Role Playing Game (RPG) Maker VX Axe," Jurnal Infotel, vo. 8, no. 1, pp. 56-63, 2016.

[13] F. A. Purnomo, E. H. Pratisto, T. NH, F. Sahrul, and I. P. Lestari, "Pembuatan Game Edukasi 'Petualangan Si Gemul' Sebagai Pembelajaran Pengenalan Daerah Solo Raya Pada Anak," J. Simetris, vol. 7, no. 2, pp. 619-626, 2016.

[14] R. I. Purwatiningsih, "Perancangan Game Edukasi Pengenalan Tokoh Pahlawan Nasional Untuk Anak Sekolah Dasar," Universitas Muhammadiyah Surakarta, 2014.

[15] E. Batuwael, A. S. . Lumenta, and V. Tulenan, "Analisa Dan Perancangan Game Edukasi Kebersihan Mulut Pada Anak Umur 5-10 Tahun Berbasis Android," E-Journal Tek. Inform., vol. 7, no. 1, pp. 1-6, 2016.

[16] A. Trisnadoli, "Analisis Kebutuhan Kualitas Perangkat Lunak Pada Software Game Berbasis Mobile," J. Komput. Terap., vol. 1, no. 2, pp. 1-8, 2015.

[17] R. Ramadan and Y. Widyani, "Game Development Life Cycle Guidelines," in International Conference on Advanced Computer Science and Information Systems (ICACSIS), 2013, pp. 95-100.

[18] A. G. Mahafi and G. Hermawan, "Game Edukasi Penyakit Malaria Dan Cara Pencegahannya," J. IIm. Komput. dan Inform., vol. 2, no. 2, pp. 19-36, 2013.

[19] E. P. A. Sugara and Mustika, "Adopsi Model DGBL-ID Pada Pengembangan Game Edukasi Onet Wawasan Nusantara," Mikrotik, vol. 9, no. 2, pp. 110-122, 2018. 